ROCZNIKI HISTORYCZNE

Rocznik LXXXI - 2015

TOMASZ JUREK (Poznań)

\title{
O czasie i okolicznościach chrztu Mieszka
}

W przededniu zbliżającej się 1050 rocznicy chrztu Polski budzi się ponownie przygasłe już poprzednio zainteresowanie początkami państwa i Kościoła ${ }^{1}$. Sam chrzest księcia Mieszka nie jest już jednak przedmiotem szerszych sporów i analiz - jak działo się z okazji badań millenijnych ${ }^{2}$. Jego ustalona w tradycji historiograficznej data (966) wydaje się pewnikiem trudnym do wzruszenia. Od kilkudziesięciu lat propaguje się też hipotetyczną datę dzienną (Wielka Sobota, przypadająca w interesującym nas roku 14 kwietnia) $)^{3}$, która coraz szerzej przebija się do powszechnej świadomości. Czy jednak rzeczywiście wierzyć powinniśmy, że Mieszko I przyjął chrzest w 966 r.?

Nasza wiedza o dacie rocznej tego wydarzenia opiera się na zapiskach rocznikarskich. Dysponujemy przekazaną przez najstarsze zachowane roczniki zapiską Mesco (Mysko) dux Polonie baptizatur ${ }^{4}$. Powszechne było zawsze przypuszczenie, że fakt ten wraz z pewnymi innymi wydarzeniami z naszych najstarszych dziejów został zapisany na bieżąco. Taki przekaz rzeczywiście trudno byłoby podważyć. Kwestionowanie ścisłości tych informacji ma już wprawdzie długą tradycję̧, ale

${ }^{1}$ Stan badań i dyskusji podsumowali ostatnio J. D o b o s z, Monarchia i możni wobec Kościoła w Polsce do początku XIII wieku, Poznań 2002, s. 25-61; D. A. S i k o r s k i, Kościół w Polsce za Mieszka I i Bolesława Chrobrego. Rozważania nad granicami poznania historycznego, Poznań 2011, s. 91-107; zob. też A. P l e s z c z y ń s k i, Die Taufe Polens - das Jahr 966, w: Religiöse Erinnerungsorte in Ostmitteleuropa. Konstitution und Konkurrenz im nationen- und epochenübergreifenden Zugriff, Berlin 2013, s. 795-803.

${ }^{2}$ G. L a buda, Studia nad początkami państwa polskiego, Poznań 1946, s. 55-79; H. Łow mi á s ki, Imię chrzestne Mieszka I, Slavia Occidentalis 19, 1948, s. 203-308 (dalej cyt. według przedruku w: tegoż, Studia nad dziejami Słowiańszczyzny, Polski i Rusi w wiekach średnich, Poznań 1986, s. 228-356); J. Wi d a j e w i c z, Chrzest Polski, Życie i Myśl 1951, nr 2, s. 443-469; J. D o w i a t, Metryka chrztu Mieszka I i jej geneza, Warszawa 1961; t e n ż e, Chrzest Polski, Warszawa 1966; P. B o g d a n o w i c z, Chrzest Polski, Nasza Przeszłość 23, 1966, s. 7-64; Z. S u ło w s k i, Chrzest Polski, Zeszyty Naukowe KUL, 1966, z. 1-2, s. 20-26; B. S t a s i e w s k i, Die Anfänge der Christianisierung Polens auf dem Hintergrund der slavischen Missionsgeschichte des frühen Mittelalters, Münster 2014 (rozprawa z 1958 r.), s. 286-297.

3 J. D ow i a t, Metryka, s. 84-86.

${ }^{4}$ Tak najstarsze zachowane redakcje, Rocznik dawny i Rocznik kapituły krakowskiej, zob. niżej, przyp. 21. Przegląd źródeł dali P. B o g d a n o w i c z, Chrzest, s. 8-9, oraz J. D o b o s z, Monarchia, s. 25-32.

5 Zob. niżej, przyp. 15-16. 
postęp badań nad średniowieczną annalistyką polską (prowadzonych głównie przez Zofię Kozłowską-Budkową i Gerarda Labudę ${ }^{6}$ ) umacniał jednak przekonanie o ich wiarogodności. W świetle wyników tych studiów znane obecnie zabytki wywodzą się zasadniczo ze wspólnego pnia, który stanowił zaginiony rocznik prowadzony przynajmniej od początków XI w. w Krakowie, określany w literaturze jako Annales Regni Polonorum deperditi (lub Rocznik kapituły krakowskiej dawny). Wchłonął on na pewno starsze zapisy, sięgające $X$ w. Wyróżnia się w wśród nich dwie podstawowe grupy. Jedną stanowią zapiski dotyczące św. Wojciecha i jego rodziny (zwane umownie Rocznikiem Gaudentego), drugą - seria zapisek dotyczących wydarzeń z najdawniejszych dziejów piastowskich: przybycia Dobrawy do Mieszka (965), chrztu (966), narodzin ich syna Bolesława (967), ordynacji pierwszego biskupa polskiego Jordana (968), śmierci tegoż Jordana (984), a może też śmierci Dobrawy (977) i śmierci Mieszka (992). Choć żaden z zachowanych roczników polskich nie zawiera wszystkich tych zapisek w komplecie, uważa się, że pochodzą one ze wspólnego źródła, którym musiały być noty prowadzone na bieżąco, prawdopodobnie na tablicy paschalnej zawierającej też jakieś zapiski annalistyczne przywiezione z Niemiec (tzw. Rocznik obcy) przez duchownego z otoczenia Mieszka i Dobrawy. Zespół tych najstarszych zapisek określa się umownie jako Rocznik Jordana ${ }^{7}$. Tak ustaloną wizję początków polskiego rocznikarstwa zakwestionował ostatnio Tomasz Jasiński Inaczej od poprzedników zidentyfikował Rocznik obcy, który z Moguncji poprzez morawski Ołomuniec trafił do Krakowa najwcześniej w 975 r. Także w Krakowie badacz ten umiejscawia powstanie zapisek dotyczących rządzącego tam od $984 \mathrm{r}$. Bolesława Chrobrego. Noty te uzupełnione następnie zostały ex post wspomnianymi informacjami z lat 965, 966, 967 (w tym zapiską o chrzcie Mieszka). T. Jasiński nie przesądzał zresztą dokładnie ani momentu dopisania tych dodatków (jedynie sugerował albo rok 984, gdy Chrobry zaczynał swe rządy w Krakowie, albo 1003, gdy obejmował władzę w Czechach) ${ }^{9}$. Nie przesądzał też, czy zapiski te wtedy powstały, czy też zostały przeniesione z pierwowzoru powstałego już wcześniej

${ }^{6}$ Z. B u d k ow a, Początki polskiego rocznikarstwa, Studia Źródłoznawcze 2, 1958, s. 81-96; G. L a b u d a, Główne linie rozwoju rocznikarstwa polskiego w wiekach średnich, Kwartalnik Historyczny 78, 1971, s. 804-839.

${ }^{7}$ Łączenie wszystkich tych zapisek w jeden zespół budzi wątpliwości, choćby dlatego, że żaden z zachowanych zabytków nie zawiera ich wszystkich w komplecie. Przypomnieć jednak należy celną uwagę Z. B u d k ow ej, Początki, s. 86, by ze względu na szczupłość kadr piszących w ówczesnej Polsce nie mnożyć domniemanych utworów.

${ }_{8}$ T. J a s i ń s k i, Początki polskiej annalistyki, w: Nihil superfluum esse. Studia z dziejów średniowiecza ofiarowane profesor Jadwidze Krzyżaniakowej, Poznań 2000, s. 129-146; t e n ż e, Rocznik poznański. Ze studiów nad annalistyką polską i czeską, w: Aetas media, aetas moderna. Studia ofiarowane profesorowi Henrykowi Samsonowiczowi w siedemdziesiątą rocznicę urodzin, Warszawa 2000, s. 664-672; t e n ż e, Rocznik obcy w „Roczniku kapituły krakowskiej”, w: Scriptura custos memoriae. Prace historyczne, Poznań 2001, s. 217-224; t e n ż e, Zagadnienie autorstwa Rocznika obcego. Przyczynek do dziejów historiografii niemieckiej X stulecia, Roczniki Historyczne 68, 2002, s. 7-25; t e n ż e, Rola Rocznika augijskiego w rozwoju annalistyki polskiej i niemieckiej, Roczniki Historyczne 69, 2003, s. 71-78; zob. też J. W e n t a, Roczniki Królestwa, w: Tekst źródła - krytyka - interpretacja, Warszawa 2005, s. 127-135.

9 T. J a s i ń s k i, Początki polskiej annalistyki, s. 137, 144. 
W wielkopolskim centrum monarchii. Narastający zasób krakowskiego rocznika uzupełniany był potem co najmniej kilkakrotnie (na pewno w drugiej połowie XI i jeszcze w połowie XIII w.) zapiskami sprowadzanymi z Czech, wśród których były też dotyczące najstarszych dziejów (np. ta o pierwszym biskupie). Propozycje te ocenił krytycznie najlepszy obecnie znawca polskiej annalistyki - Wojciech Drelicharz. Doceniając wagę pewnych ustaleń (zwłaszcza w sprawie Rocznika obcego), opowiedział się jednak za zasadniczą aktualnością konstrukcji wypracowanej przez Z. Budkową i G. Labudę ${ }^{10}$. Jego sceptycyzm dotyczy jednak spraw z naszego punktu widzenia drugorzędnych. Udowodnienie przez T. Jasińskiego, że Rocznik obcy został sprowadzony do Polski (i to do Krakowa) dopiero po 975 r., stawia pod znakiem zapytania wcześniejsze prowadzenie jakichś zapisek w Wielkopolsce. Warto zresztą przypomnieć, że także Z. Budkowa, najdokładniej analizująca najstarsze zapiski, uznawała jedynie, że powstawały one „w miarę współcześnie” z wydarzeniami. Broniła zasadniczej wiarogodności dat, co stanowiło dla niej rękojmię, że zapisów dokonywano za dobrej jeszcze pamięci (a nie po kilkudziesięciu latach). Nie upierała się natomiast przy prowadzeniu roczników na bieżąco i za zupełnie oczywiste uznawała drobne (nawet kilkuletnie) przesunięcia w datach, uzasadnione choćby faktem, że pierwotne zapisy wnoszone były na ciasnych marginesach tablic paschalnych $^{11}$. Dopiero G. Labuda, powołując się na te ustalenia, lansować zaczął i utrwalił pogląd, że najstarsze zapiski powstawać musiały współcześnie z wydarzeniami ${ }^{12}$. Wiarę w miarodajność danych chronologicznych roczników podważał też ostatnio Dariusz A. Sikorski. Pokazał on, odwołując się do lepiej rozpoznanych analogii zachodnioeuropejskich, że normą w annalistyce było wnoszenie wpisów ,skokowo”, pewnymi większymi partiami co kilka-kilkanaście lat, nie zaś systematycznie rok po roku ${ }^{13}$. Zauważmy, że zapiski tworzące Rocznik Gaudentego na pewno powstały ex post, spisane po latach (nikt przecież na bieżąco nie odnotowywałby dat narodzin rodziców św. Wojciecha) ${ }^{14}$.

Krytyczne rozpoznanie problematyki nie upoważnia więc bynajmniej do uznawania naszych najstarszych zapisek annalistycznych, a zwłaszcza ich dat, za absolutnie pewne. Należy próbować ich weryfikacji na podstawie niezależnych źródeł. Od dawna wskazywano na wątpliwości co do daty narodzin Chrobrego (967) ${ }^{15}$ i jej miejsca w sekwencji dat ślubu rodziców (965) i chrztu ojca (966). Podejrzewano tu często próbę stronniczego pokazania, że Bolesław urodził się już z chrześcijańskich

${ }^{10}$ W. D r e 1 i c h a r z, Idea zjednoczenia królestwa w średniowiecznym dziejopisarstwie polskim, Kraków 2012, s. 22-47.

11 Z. B u d k o w a, Początki, s. 82-85.

${ }^{12} \mathrm{G}$. L a b u d a, Jeden czy dwa roczniki niemieckie u podstaw polskiego rocznikarstwa?, Studia Źródłoznawcze 39, 2001, s. 9: „wszystkie one zostały zapisane współcześnie w Polsce"; zob. K. J a s iń s k i, Najdawniejsze roczniki krakowskie, Kwartalnik Historyczny 88, 1981, s. 464-465.

${ }^{13}$ D. A. S i k or s k i, Kościół, s. 38-49.

14 Z. B u d k ow a, Początki, s. 85.

15 Podana w Roczniku kamienieckim, Monumenta Poloniae historica (dalej cyt.: MPH), t. II, Lwów 1872, s. 828, oraz szeregu późniejszych roczników (zestawia je O. B a lze r, Genealogia Piastów, wyd. 2, Kraków 2005, s. 75), częściowo pod pomylonymi datami (zob. niżej, przyp. 22). 
rodziców ${ }^{16}$. Przypomnieć też trzeba relację Thietmara, powołującego się na dwie wersje - jakoby Dobrawa, pragnąc pozyskać sympatię swego pogańskiego męża, łamała Wielki Post w jednym roku lub nawet w trzech kolejnych latach ${ }^{17}$ (czego nie dałoby się już pogodzić $\mathrm{z}$ wersją przekazaną $\mathrm{w}$ rocznikach). Wątpliwości budzi też data śmierci Jordana $(984)^{18}$, która nie zgadza się z podaną przez Thietmara informacją, że jego następca, Unger, umarł 9 VI 1012 r. w trzydziestym roku od swej konsekracji biskupiej ${ }^{19}$ (przypadającej zatem na drugą połowę 982 r.). Istnieje jednak wiele możliwości wyjaśnienia tej rozbieżności ${ }^{20}$. Nie potrafimy więc w żadnym wypadku wyjść poza same wątpliwości i podejrzenia, nie ma bowiem twardego źródłowego dowodu na rocznikarską pomyłkę. Najważniejsza i tak pozostaje data chrztu.

Próbę weryfikacji zacząć trzeba od ustalenia właściwej daty, jaka figurowała w Annales Regni Polonorum deperditi (traktując to określenie umownie, niezależnie od sporów o dokładny kształt i genezę tego prawzoru polskiej annalistyki). Nawet najstarsze przekazy, korzystające bezpośrednio z tego zaginionego rocznika, nie podają tej daty zgodnie. Pierwszym jest zachowany w oryginale Rocznik dawny z ok. 1120 r., w którym chrzest Mieszka odnotowany został pod 967 r. Z kolei w Roczniku kapituły krakowskiej, też znanym z oryginału, a powstałym w 1266 r., odpowiednia zapiska figuruje pod $966 \mathrm{r}^{21}$ Liczne dalsze redakcje podające tę datę są zależne od Rocznika kapitulnego i nie mają dla nas samodzielnej wartości. Z kolei w rocznikach późnośredniowiecznych podawane są różne daty, będące wynikiem zwykłych błędów kopistów bądź też zawiłych interpretacji kolejnych redaktorów ${ }^{22}$. I one nie wnoszą nic do kwestii rekonstrukcji zapisu w Annales Regni Polonorum deperditi. Mamy więc do wyboru dwie możliwości: 966 lub 967. Teoretycznie uzasadnione mogłoby być danie pierwszeństwa tej drugiej wersji, jako przekazanej przez starszy Rocznik dawny ${ }^{23}$. W Roczniku tym jednak wszystkie daty aż do 1000 r., których większość mamy dobrze poświadczoną innymi źródłami, zostały przesunięte o jeden rok. Przypuszczać wolno, że jeszcze w 1120 r. Annales Regni Polonorum deperditi mogły mieć postać zapisów na marginesach tablicy paschalnej, a przy ich odpisywaniu

${ }^{16}$ S. Z a krzew s ki, Bolesław Chrobry Wielki, Lwów 1925, s. 45, 369; J. D o w i a t, Metryka, s. 147-150; zob. K. J a s iń s k i, Rodowód pierwszych Piastów, wyd. 2, Poznań 2004, s. 81-82.

${ }^{17}$ Die Chronik des Bischofs Thietmar von Merseburg, IV 56, wyd. R. Holtzmann, Monumenta Germaniae historica (dalej cyt.: MGH), Scriptores rerum Germanicarum, nova series, t. IX, Berlin 1935, s. 194; tłum. pol.: Kronika Thietmara, wyd. M. Z. Jedlicki, Poznań 1953, s. 220.

18 Podana tylko w Roczniku kapituły poznańskiej, MPH series nova, t. VI, Warszawa 1962, s. 23.

19 Thietmar VI 65, s. 365; thum pol., s. 406.

${ }^{20}$ D. A. S i k o r s k i, Kościół, s. 186-194.

${ }^{21}$ Oba wydane w MPH series nova, t. V, wyd. Z. Kozłowska-Budkowa, Warszawa 1978, s. 5,43 .

22 P. W ę c o w s k i, Początki Polski w pamięci historycznej późnego średniowiecza, Kraków 2014, s. 239, 278.

${ }^{23}$ Tak W. A b r a ha m, Organizacja Kościoła w Polsce do połowy XII wieku, wyd. 3, Poznań 1962, s. 104. 
łatwo było popełnić tego rodzaju pomyłkę. Systematyczne przesunięcie dat w Roczniku dawnym wskazuje, że w jego podstawie chrzest zapisany być musiał pod $966 \mathrm{r}$. - a więc tak samo, jak w Roczniku kapitulnym. Oba przekazy okazują się zatem zgodne, co stanowi dla nas rękojmię poprawności daty 966.

To tę datę poddać zatem musimy weryfikacji. Współczesnych źródeł, które mogłyby do tego posłużyć, nie ma niestety wiele. Odwołać się przyjdzie do przekazu saskiego kronikarza Widukinda z Korvei. Był on niewątpliwie bystrym obserwatorem, dzieło swe kończył w tym właśnie czasie (ok. 968 r.), a ową końcową partię, dodaną do zamkniętego już wcześniej korpusu ${ }^{24}$, poświęcił specjalnie postaci saskiego arystokraty, banity Wichmana, co skupiało uwagę na sprawach wschodniego pogranicza Rzeszy. Widukind wymienia dwukrotnie Mieszka ${ }^{25}$. Po raz pierwszy w opisie przewag zbiegłego do wieleckich Redarów Wichmana, który napadał „dalej mieszkających barbarzyńców”, wśród nich „króla Mieszka, pod którego władzą znajdowali się Słowianie zwani Licicaviki”, któremu zadał dwie klęski. Ponieważ w następnym zaraz rozdziale mowa jest o podboju Łużyczan przez margrabiego Gerona, co - jak wiemy skądinąd - nastąpiło w 963 r. $^{26}$, do tego czasu odnieść trzeba najpewniej i relację o sukcesach Wichmana. Nieco dalej kronikarz opowiada o kolejnej odsłonie tych walk. Wichman chciał znów zaatakować Mieszka, „przyjaciela cesarza”, ten jednak ściągnął posiłki od swego teścia, Bolesława czeskiego, i tym razem odniósł zwycięstwo w bitwie. Uciekający z pogromu Wichman został osaczony i zginął, przed śmiercią oddając miecz ludziom Mieszka, aby ten przekazał tę broń swemu „,przyjacielowi cesarzowi”. Odpowiedzią na te wypadki jest przytoczony dalej list cesarski datowany w Kapui 18 stycznia, niewątpliwie 968 r. Bitwa musiała zostać stoczona kilka miesięcy wcześniej, jesienią 967 r., a wskazać można nawet datę dzienną, wiemy bowiem, że zgon Wichman nastąpił 22 września ${ }^{27}$. W każdym z tych epizodów Mieszko występuje wyraźnie w innym charakterze. Za pierwszym razem jako „król barbarzyńców”, niewątpliwie jeszcze poganin. Za drugim razem jest już amicus imperatoris. Wprawdzie polityczna ,przyjaźń” możliwa była także z poganami, ale kontekst tej relacji - a zwłaszcza opisane zachowanie Wichmana, krewniaka i przybranego syna cesarza, który uznał Mieszka za równego sobie rangą - pokazuje,

${ }^{24}$ D. A. S i k o r s k i, O stosunkach polsko-niemieckich w X i XI wieku, Studia Historica Slavo-Germanica 26, 2004/2005 (wyd. 2006), s. 264-266.

${ }^{25}$ Die Sachsengeschichte des Widukind von Korvei, III 66 i 69, wyd. H.-E. Lohmann, P. Hirsch, Scriptores rerum Germanicarum, Hannover 1935, s. 141, 144-145.

${ }^{26}$ Reginonis abbatis Prumensis Chronicon cum continuatione Treverensi, wyd. F. Kurze, Scriptores rerum Germanicarum, Hannover 1890, s. 173.

27 Przyjmuje się powszechnie (zob. Ch. L ü b k e, Regesten zur Geschichte der Slaven an Elbe und Oder (von Jahr 900 an), t. II, Berlin 1985, s. 200-202; G. A 1 t h off, Wichmann, w: Lexikon des Mittelalters, t. IX, 1999, kol. 60) tę właśnie datę, pod którą nekrolog klasztoru św. Michała w Lüneburgu notuje: Wichmannus comes et multi alii occisi (A. Ch. W e d e k in d, Noten zu einigen Geschichtsschreibern, cz. 3, Braunschweig 1833, s. 70). W tym samym nekrologu mamy jednak też innych Wichmanów: 23 IV Wigmam comes (s. 30), 12 V Wichmannus comes (s. 36), 9 X Vuichmannus comes + et occisus (s. 75), a kolejnych znajdujemy w nekrologu merseburskim (MGH Libri memoriales et necrologia, nova series, t. II, Hannover 1983): 10 i 11 VII Uuigmanus (s. 8-9), 5 X Wigmannus comes, 12 X Vuigmannus comes (s. 13); zob. indeks, tamże, s. 24-25. 
że mamy tu już do czynienia z chrześcijańskim władcą ${ }^{28}$. Podnoszono już co prawda, że z relacji Widukinda trudno wyciągać tego rodzaju wnioski. Oba epizody należą wszak do części kroniki powstałej w jednym czasie, a więc kronikarz opisywał w niej Mieszka takiego, jakim znał go w momencie pisania. Charakterystyka Mieszka w obydwóch ustępach jest jednak tak wyraźnie zróżnicowana, że musi to być świadomy zabieg autora, kreślącego tę postać stosownie do okoliczności, w jakich się miała pojawiać - raz jako poganina, raz zaś jako chrześcijanina ${ }^{29}$. Otrzymujemy zatem wyraźny przedział czasowy, w którym zmienił się status księcia Mieszka. Nastąpić to musiało między 963 a jesienią $967 \mathrm{r}$.

Dalsze uściślenie możliwe jest już tylko na podstawie obserwacji kontekstu politycznego. Zastanawiano się oczywiście nad nimi często w literaturze ${ }^{30}$. Podstawowym źródłem jest, obok cytowanego już Widukinda, przekaz późniejszego nieco (zm. 1018) kronikarza Thietmara z Merseburga. Podaje on mianowicie, że saski margrabia Gero podbił Łużyczan i Słupian (Selpuli), a także podporządkował sobie Mieszka $^{31}$. Wiadomo skądinąd, przypomnijmy, że podbój Łużyc nastąpił w $963 \mathrm{r}$. Przyjmowano więc tradycyjnie $\mathrm{w}$ historiografii istnienie jakiegoś układu między Geronem a Mieszkiem, w związku z którym ten ostatni zgodzić się musiał na płacenie trybutu na rzecz cesarstwa (o którym to trybucie Thietmar wyraźnie wspomina $\mathrm{w}$ innym miejscu ${ }^{32}$ ), a prawdopodobnie także na przyjęcie chrztu ${ }^{33}$. Tę powszechnie kiedyś akceptowaną wykładnię podważyło zakwestionowanie wiarogodności przekazu Thietmara przez Kazimierza Tymienieckiego, a zwłaszcza Gerarda Labudę, który w pełni rozwinął jego pomysł ${ }^{34}$. Dowodzili oni, że kronikarz po prostu źle zrozumiał relację Widukinda, na której wyłącznie się opierał - i podane przez tego ostatniego wiadomości o zwycięstwach Wichmana odniósł omyłkowo do Gerona. $\mathrm{W}$ istocie nie było zatem żadnego starcia Mieszka z saskim margrabią. Rozwiązanie

${ }^{28}$ P. K e h r, Das Erzbistum Magdeburg und die erste Organisation der christlichen Kirche in Polen, Abhandlungen der Preussischen Akademie der Wissenschaften, Philosophisch-Historische Klasse 1920, nr 1, s. 6 (przedruk w: tegoż, Ausgewählte Schriften, Göttingen 2005, t. II, s. 1104): „Das eine kann wohl als sicher angenommen werden, daß Herzog Meszko im Jahre 967 schon Christ war, weil Widukind von Korvei ihn amicus imperatoris nennt".

${ }^{29}$ W. A b r a h a m, Organizacja, s. 102.

${ }^{30}$ Pewne podsumowanie dał ostatnio D. A. S i k o r s k i, Kościół, s. 91-107.

31 Thietmar II 14, s. 54; thum. pol., s. 58.

${ }^{32}$ Thietmar II 29, s. 74; thum. pol., s. 88; zob. T. J u r e k, Usque in Vurta fluvium. Nad trybutem Mieszkowym, Kwartalnik Historyczny (w druku).

${ }^{3}$ Tak już S. Z a krzews ki, Mieszko I jako budowniczy państwa polskiego, Warszawa 1921 (wyd. 2, Kraków 2006, s. 51-54); t e n ż e, Okres do schyłku XII w., w: Historia polityczna Polski, cz. 1, Warszawa 1920 (Encyklopedia polska, t. V, cz. 1 ), s. 32. Taka rekonstrukcja wydarzeń utrwalona jest w literaturze niemieckiej, zob. np. R. H o l t z m a n n, Geschichte der sächsischen Kaiserzeit (900-1024), München 1941, s. 188-189; J. F ri e d, Der Weg in die Geschichte. Die Ursprünge Deutschlands bis 1024, Berlin 1998, s. 635, 659; H. Kelle r, G. Alth off, Die Zeit der späteren Karolinger und der Ottonen. Krisen und Konsolidierungen 888-1024 (Gebhardt. Handbuch der deutschen Geschichte, wyd. 10, t. III), Stuttgart 2008, s. 236.

${ }^{34}$ K. Ty m i e n i e c k i, Widukind i Thietmar o wypadkach z roku 963, Roczniki Historyczne 12, 1936, s. 95-106; G. L a b u d a, Studia, s. 5-54; t e n ż e, Mieszko I, Wrocław 2002, s. 72-81; t e n ż e, Pierwsze wieki monarchii piastowskiej, Poznań 2012, s. 38 n. 
takie zostało dość powszechnie przyjęte ${ }^{35}$, ale nie wszystkich jednak przekonało. Są badacze broniący wiarogodności Thietmara ${ }^{36}$. Wskazują oni, że kronikarz ten nie opierał się wyłącznie na Widukindzie, miał bowiem w stosunku do niego dodatkowe wiadomości (wśród ludów pokonanych przez Gerona podaje wszak jeszcze Słupian, Widukindowi nieznanych). Pisząc z nieco odleglejszej perspektywy mógł zwracać uwagę na sprawy, których rangi Widukind jeszcze nie doceniał. Przede wszystkim zaś, choć narracja obu kronikarzy toczy się w podobnym układzie (co rodzi wrażenie zależności Thietmara od poprzednika), to jednak traktują oni w istocie o różnych sprawach - o ile Widukinda interesował niemal wyłącznie los Wichmana, o tyle Thietmar eksponował sukcesy Gerona. Nie ma więc w istocie podstaw, aby całkowicie odrzucać relację merseburskiego dziejopisa. W konsekwencji trzeba przyjać, że rzeczywiście w 963 r. doszło do podporządkowania Mieszka Sasom, choć - jak starałem się to pokazać $\mathrm{w}$ innym miejscu ${ }^{37}$ - nie wiązało się to raczej z militarną porażką (której nie zauważyły wszak inne źródła). Wyobrazić sobie można, że pobity świeżo przez Wichmana książę piastowski na wieść o zwycięstwach Gerona, docierającego już do Odry, nie czekał na dalszy rozwój wydarzeń, ale sam poddał się saskiemu margrabiemu i zgodził się płacić trybut.

Kwestia układu z Geronem ma spore znaczenie dla sprawy chrztu Mieszka. Historycy, którzy przyjmowali istnienie takiego układu, w dość oczywisty sposób wiązali z nim także zobowiązanie do przyjęcia nowej wiary, zrealizowane w najbliższych latach. Gerard Labuda, odrzuciwszy relację Thietmara, a więc i układ z Geronem, zbudował własną wizję wypadków ${ }^{38}$. Informacje Widukinda o walkach z Wieletami (potwierdzone zresztą przez relację żydowskiego podróżnika Ibrahima ibn Jakuba ${ }^{39}$ ) skojarzył mianowicie z faktem małżeństwa Mieszka z czeską księżniczką Dobrawą. Jako że za mariażem tym krył się na pewno sojusz polityczny, G. Labuda dostrzegł tu próbę rozerwania tradycyjnego przymierza czesko-wieleckiego, groźnego dla rosnącego w siłę władztwa piastowskiego. Przypomnijmy cytowany już przekaz Widukinda o czeskich posiłkach, biorących udział w zwycięskiej bitwie z Wichmanem. Naturalną konsekwencją nowego układu politycznego stać się musiało przyjęcie przez Mieszka chrześcijaństwa, najpewniej nie bez osobistego wpływu żony chrześcijanki.

35 Ostatnio T. J a s i ń s k i, Czy państwo polskie za Mieszka I było suwerenne?, w: Studia nad dawną Polską, t. II, Gniezno 2009, s. 9-19; t e n ż e, Początki organizacji kościelnej w Polsce, w: Tu się wszystko zaczęło. Rola Poznania w państwie pierwszych Piastów, Poznań 2010, s. 87-94.

${ }^{36}$ M. Z. J e d li c ki, Stosunek prawny Polski do Cesarstwa do r. 1000, Poznań 1939, s. 20-27; H. L u d a t, Die Anfänge des polnischen Staates, Krakau 1942, s. 26; H. Ł o w m i a ń s k i, Początki Polski, t. V, Warszawa 1973, s. 517-521; J. S tr z e l c z y k, Mieszko Pierwszy, Poznań 1992, s. 81-93; J. S o c h a c k i, Stosunki publicznoprawne między państwem polskim a Cesarstwem Rzymskim w latach 963-1102, Gdańsk 2003, s. 55; S. R o s i k, Początki Polski w kronikach niemieckich X-XI w. (w kręgu wiadomości Widukinda z Korwei), w: Kolory i struktury średniowiecza, Warszawa 2004, s. 236-240; D. A. S i k o r s ki, O stosunkach polsko-niemieckich, s. 263-266.

37 T. J u r e k, Usque in Vurta fluvium.

${ }^{38}$ G. L a b u d a, Studia, s. 55-79; t e nż e, Mieszko, s. 87-102; t e n ż e, Pierwsze wieki, s. $46 \mathrm{n}$.

39 Zob. niżej, przyp. 63. 
Nawiązanie stosunków trybutarnych z cesarstwem (którym zaprzeczyć było nie sposób) G. Labuda łączył z nieco późniejszymi (965/966) negocjacjami z cesarzem ${ }^{40}$, które milcząco uznał jednak za niewiążące się bynajmniej ze sprawą chrztu (choć właśnie takie przesunięcie ich chronologii czyniło ten związek wręcz oczywistym). Koncepcja ta - nieprzypadkowo opublikowana w 1946 r., a wypracowana podczas mrocznych lat okupacji niemieckiej - zyskała następnie szeroki oddźwięk w polskiej historiografii, zwłaszcza $\mathrm{w}$ pracach ogólniejszych i popularnych ${ }^{41}$. Niezależnie od logicznej zwartości interpretacji wydarzeń politycznych, jej atrakcyjność wynikała z mocnego wyeksponowania i utwierdzenia tezy o przyjęciu chrztu przy pośrednictwie czeskim, co pozwalało wyminąc drażliwą politycznie kwestię ewentualnych wpływów niemieckich ${ }^{42}$. Choć więc G. Labuda deklarował odejście od nacechowanych kompleksami antyniemieckimi tradycji polskiej historiografii, w istocie wpisywał się - przy korektach faktografii - w ten sam nurt, który od czasów Naruszewicza podkreślał, że Mieszko przyjął chrzest z Czech, aby uniknąć przyjmowania go od Niemców ${ }^{43}$ (bardzo wcześnie zresztą pojawiać się też zaczęły głosy rozsądku, przyznające, że chrześcijaństwo i tak musiało przecież przyjść do nas z Niemiec ${ }^{44}$ ). W ujęciu G. Labudy wielki zamysł przyjęcia nowej wiary wykuwał się wyłącznie w kontaktach między Mieszkiem, jego żoną, jej czeską rodziną, a także ewentualnie papiestwem, do którego piastowski książę wystąpić miałby z prośbą o przysłanie misjonarzy (na co zresztą nie ma żadnych dowodów źródłowych). Cesarz stawał się w takim układzie zupełnie niepotrzebny. Ten właśnie aspekt ze szczególnym uznaniem podkreślał potem Piotr Bogdanowicz ${ }^{45}$. Z kolei Józef Widajewicz gotów był pójść podobną drogą jeszcze dalej i dowodził, że Mieszko ochrzcił się nie tylko bez udziału Niemców, ale wręcz wbrew nim, a nawet w tajemnicy przed cesarzem - na co dowód znajdował w braku informacji na ten temat w relacji Ibrahima ibn Jakuba, opartej wszak na informacjach uzyskanych na dworze cesarskim ${ }^{46}$. Nawet

${ }^{40}$ G. L a b u d a, Studia, s. 161-162.

${ }^{41}$ Np. A. G i e y s zt o r, w: Historia Polski, t. I, cz. 1, Warszawa 1957, s. 162-164; H. S a m s on ow i c z, Historia Polski do roku 1795, wyd. 2, Warszawa 1973, s. 18-19; J. W y r o z u m s k i, Dzieje Polski piastowskiej (VIII w. - 1370), Kraków 1999 (Wielka historia Polski, t. 2), s. 79; S. S z c z u r, Historia Polski. Średniowiecze, Kraków 2002, s. 48-50; M. K. B a r a ń s k i, Dynastia Piastów w Polsce, Warszawa 2005, s. 42-48; B. S t a s i e w s k i, Die Anfänge, s. 295. Zob. też G. L a b u d a, Studia, wyd. 2, t. I, Poznań 1987, s. 443-455. Jedynie B. M i śk i e w i c z, w: Dzieje Polski, wyd. 4, Warszawa 1993, s. 125, choć uczeń G. Labudy, przyjął tezy Łowmiańskiego.

${ }^{42}$ G. L a b u d a, Studia, s. 77: „Pośrednictwo niemieckie w Rzymie było zupełnie niepotrzebne". Dodać trzeba, że postawa taka była zrozumiała jako reakcja wobec stanowiska nauki niemieckiej, mocno instrumentalizującej politykę wschodnią Ottona w duchu aktualnych tendencji (zob. G. A 1 th off, Otto der Große und die neue europäische Identität, w: Der Hoftag in Quedlinburg 973. Von den historischen Wurzeln zum Neuen Europa, Berlin 2006, s. 7-9).

${ }^{43}$ Zob. P. B og d a n ow i c z, Chrzest, s. $18 \mathrm{n}$.

${ }^{44}$ W. A br a h a m, Organizacja, s. 104-105.

${ }^{45}$ P. B o g d a n o w i c z, Chrzest, s. 22: „Wszystkie te sugestie przyznające »Niemcom«, i to wbrew źródłom, udział decydujący w dziele chrystianizacji Polski Mieszka I - są nie do przyjęcia”.

${ }^{46}$ J. W i d a j e w i c z, Chrzest, s. 450. 
ci badacze, którzy czuli, że udziałowi cesarza trudno całkowicie zaprzeczać, pod naporem communis opinio cofali $\operatorname{się}^{47}$.

Krytycznie do tez G. Labudy podszedł natomiast od razu Henryk Łowmiański ${ }^{48}$. Nie zamierzał on usuwać cesarza Ottona z rekonstruowanego przez siebie obrazu wydarzeń prowadzących do chrztu Mieszka. Broniąc wiarogodności Thietmara, przyjmował układ Mieszka z Geronem (datując go co prawda z przesunięciem na 964 r.), obejmujący obietnicę chrztu. Realizując to zobowiązanie, piastowski książę - zakładał Łowmiański - zjawić się musiał przed obliczem cesarskim. Do spotkania tego doszło prawdopodobnie w Kolonii na Boże Narodzenie 965 r., gdzie poczyniono dalsze uzgodnienia, skutkiem których Mieszko mógł przyjąć w 966 r. chrzest - czego dokonał niewątpliwie u siebie w kraju. Słuszne i trzeźwe myśli (zwłaszcza co do niezbędności udziału cesarza w całej sprawie) sąsiadowały tu ze słabiej uzasadnionymi pomysłami (jak zwłaszcza hipoteza o podróży Mieszka do odległej Kolonii, związana z inną, spinającą całość wywodu, tezą o leodyjskim pochodzeniu pierwszego biskupa polskiego Jordana). To właśnie dlatego rekonstrukcja H. Łowmiańskiego nie uzyskała szerszej akceptacji ${ }^{49}$. Warunkom pierwszych latach powojennych bardziej odpowiadała konkurencyjna wizja G. Labudy, potem zaś coraz silniej działał potężny autorytet tego właśnie uczonego. Okolicznościami chrztu zajmował się też później Jerzy Dowiat ${ }^{50}$. Próbował on dokonać syntezy różnych wątków. Zgadzał się, że Mieszko pragnął uniknąć nacisków niemieckich i w związku z tym omijał cesarza, wybierając pośrednictwo czeskiego teścia. Przyznawał jednak zarazem aktywną rolę kleru niemieckiego (acz nie saskiego, lecz bawarskiego), skoro Czesi nie posiadali wtedy własnego biskupa. Chrzest Mieszka odbyć się miał zatem najpewniej w Ratyzbonie 14 IV 966 r. I w tym wywodzie ciekawe i zdrowe myśli sąsiadowały z niepotrzebnie mnożonymi domysłami w różnych sprawach szczegółowych (np. w kwestii pierwotnego imienia Mieszka, jednoczesnego chrztu jego urodzonego w istocie już wcześniej syna Bolesława itp.). Właśnie ta obudowa pomniejszych hipotez, często stawianych bardzo swobodnie, spowodowała, że cała koncepcja J. Dowiata przyjęta została sceptycznie.

Zasadnicza, jak sądzę, różnica w poglądach wymienionych badaczy polega na tym, czy uznają oni jakikolwiek udział cesarza w dziele konwersji Mieszka, czy też go odrzucają. Stanowisko wykluczające wpływ cesarski nie liczyło się z realiami epoki, w której cesarz uważał szerzenie wiary chrześcijańskiej za jedno ze swych głównych zadań, i to zarówno ze względów ideologicznych, jak i czysto politycznych. Otto Wielki, który niedawno odświeżył blask władzy cesarskiej i był żywo zainteresowany ekspansją na wschodzie, a właśnie w latach sześćdziesiątych pracował usilnie nad swą ulubioną ideą fundacji nowej metropolii kościelnej dla chrystianizowanej

${ }^{47}$ T. S i 1 n i c k i, Początki organizacji kościoła w Polsce za Mieszka I i Bolesława Chrobrego, w: Początki Państwa Polskiego. Księga Tysiąclecia, t. I, Poznań 1962, s. 329: „Pośrednictwo cesarza jest prawdopodobne, nie wydaje się jednak konieczne".

${ }^{48}$ H. Łow mi án s ki, Imię, s. 339-345; potem nieco szerzej te n ż e, Początki Polski, t. V, s. 575-590.

49 Zob. G. L a bu d a, Studia, wyd. 2, t. I, 448 n.; t e n ż e, Jakimi drogami przyszło do Polski chrześcijaństwo?, Nasza Przeszłość 69, 1988, s. 39-82.

${ }^{50} \mathrm{~J}$. D ow i a t, Metryka. 
Słowiańszczyzny, nie mógł pozostawać obojętny wobec planów nawrócenia jednego z najpotężniejszych władców słowiańskich i trudno też wyobrazić sobie, że ten zabiegający o łaskę chrztu „barbarzyńca” mógłby pozwolić sobie na świadome bojkotowanie cesarza. Sam G. Labuda we wcześniejszym, napisanym jeszcze przed wojną, studium ${ }^{51}$ niezwykle trzeźwo wskazywał, dyskutując nawet $\mathrm{z}$ historykami niemieckimi, że papiestwo (któremu potem przypisywał kluczową rolę w organizowaniu misji ${ }^{22}$ ) nie odgrywało $\mathrm{w}$ tym czasie samodzielnej roli i nie było $\mathrm{w}$ stanie prowadzić polityki sprzecznej z intencjami i interesami cesarza. Próbę wyeliminowania cesarstwa $\mathrm{z}$ rekonstrukcji wydarzeń związanych z chrztem Mieszka uznać więc trzeba za koncepcję zrodzoną z antyniemieckich uprzedzeń, dziś trudną już do obrony. Dodajmy do tego jeszcze podnoszoną wyżej okoliczność, że istnieć musiał jakiś układ polityczny między Mieszkiem a Ottonem, i to niezależnie od spornej interpretacji rozważanego ustępu Thietmara. Faktem niedającym się zakwestionować pozostaje bowiem trybut płacony przez Mieszka (co zaświadcza Thietmar) oraz „przyjaźń”, łącząca go z cesarzem (w świetle relacji Widukinda). Musiały one zostać ustalone w ramach jakiegoś porozumienia, które zostało zawarte bardzo wcześnie, w 963 lub 965/966 r. Dopuszczać nawet można kilka kolejnych układów, o zmieniających się warunkach, ponieważ stosunki trybutarne wydają się formą surowszą niż „,przyjaźń" ${ }^{53}$. Możliwe jednak, że mamy tu do czynienia tylko z dwiema różnymi interpretacjami tego samego stosunku, mniej (u Thietmara) lub bardziej (u Widukinda) przychylnymi piastowskiemu władcy ${ }^{54}$. W każdym razie istnienie stosunków politycznych Mieszka $\mathrm{z}$ cesarzem w tym samym czasie, w którym decydowała się sprawa przyjęcia chrztu, nie pozwala wątpić w związek obu tych faktów. Jak celnie ujął to H. Łowmiański, „przyjęcie chrztu było sprawą polityczną, traktowaną iunctim z zawarciem paktu przyjaźni z cesarzem" ${ }^{55}$.

Powinniśmy więc przede wszystkim próbować ustalić, w jaki sposób Mieszko stał się amicus imperatoris. To użyte przez Widukinda pojęcie jest wieloznaczne, tym bardziej że kronikarz wprowadził je raczej nie w znaczeniu ścisłego terminu prawno-politycznego (w rodzaju antycznego amicus populi Romani), lecz chyba potocznym. Zwrot ma konotację biblijną - Żydzi mówią wszak do Piłata non es amicus Caesaris (J 19:12) - co nadaje mu bardziej obiegowego wymiaru. U Widukinda słowa te pełnią wreszcie istotną rolę narracyjną. W opowieści o złym Wichmanie, który zdradził swego dobroczyńcę-cesarza i został za to ukarany, w roli mściciela obrażonej sprawiedliwości pojawia się właśnie ów cesarski przyjaciel. Powstaje wręcz para - z jednej strony Wichman, który przez zdradę zmarnował swą przyrodzoną godność, z drugiej zaś Mieszko, niedawny poganin, który dzięki swemu oddaniu na oczach czytelnika

${ }^{51}$ G. L a b u d a, Magdeburg i Poznań (Założenie arcybiskupstwa magdeburskiego i biskupstwa poznańskiego na tle wschodniej polityki misyjnej Ottona Wielkiego), Roczniki Historyczne 14, 1938, s. 185-238 (przedruk w: tegoż, Studia, wyd. 2, t. I, s. 355-410).

${ }^{52}$ Krytycznie o takim podejściu D. A. S i k o r s k i, Kościół, s. 314-318; t e n ż e, Początki Kościoła w Polsce. Wybrane problemy, Poznań 2012, s. 145-222.

${ }^{53}$ H. L u d a t, Die Anfänge, s. 28, 33-35.

${ }^{54}$ A. P les z c zyńs ki, Niemcy wobec pierwszej monarchii piastowskiej (963-1034). Narodziny stereotypu. Postrzeganie i cywilizacyjna klasyfikacja władców Polski i ich kraju, Lublin 2008, s. 64-71.

55 H. Łow mi án s ki, Imię, s. 344. 
wyrasta na cesarskiego przyjaciela. Zestawienie to buduje odpowiednie napięcie fabularne. Niezależnie jednak od wszystkich tych zastrzeżeń i wieloznaczności, zwrot amicus imperatoris ma jednak na pewno określony wymiar polityczny - podkreśla w tej opowieści bliskość stosunków Mieszka z Ottonem Wielkim. Badania Vereny Epp pokazały daleko idącą trwałość wyobrażeń związanych z polityczną ,,przyjaźnią", począwszy od antyku przez całe wczesne średniowiecze ${ }^{56}$. Amicitia między nierównorzędnymi partnerami (jak w naszym przypadku) pokrywała często tendencje imperialne silniejszej ze stron. Dla nas szczególnie istotna jest konstatacja, że amicitia jako stosunek z samej swej istoty osobisty zawiązana być powinna w zasadzie w toku bezpośredniego spotkania - choć cytowana badaczka przytacza aż siedem sposobów ustanawiania przyjaźni politycznych ${ }^{57}$, różnice między nimi wynikają przeważnie ze środków umocnienia takiej umowy, a ze względów komunikacyjnych oczywisty wydaje się wymóg osobistego kontaktu ${ }^{58}$. Nierównorzędny status partnerów wskazuje jednoznacznie, że to Mieszko musiał przybyć do Ottona. Trzeba więc prześledzić itinerarium cesarskie ${ }^{59}$. Otto długo bawił w Italii, do Niemiec zjechał zaś dopiero na samym początku 965 r. i spędził ponad rok, ,zachęcając swoich do pokoju i zgody"60. W dniu 23 I 965 r. był na Reichenau, całą wiosnę widać go nad Renem, po czym z Kolonii (2-8 VI) podążył na wschód, do Magdeburga, gdzie jego pobyt poświadcza szereg dokumentów wystawionych między 26 VI a 9 VII. Przez całe lato i jesień widać go potem we wschodniej Saksonii (Kwedlinburg, Wallhausen, Merseburg), po czym oddalił się ku zachodowi, przez Brüggen (12 XII) docierając do Kolonii (gdzie spędził Boże Narodzenie i pozostał co najmniej do 8 I 966 r.). Przez pierwsze miesiące 966 r. podróżował po niderlandzkich kresach cesarstwa, po czym udał się znów ku wschodowi, przez Duisburg (1 III) przybywając do Kwedlinburga (22-23 IV), gdzie celebrował kolejny zjazd. W lipcu był jeszcze w Saksonii, po czym pojechał nad Ren i oddalił się ponownie do Italii (gdzie był już dowodnie na początku grudnia). W tych ramach umieścić należy spotkanie Ottona z Mieszkiem. H. Łowmiański, przypomnijmy, sugerował, że doszło do niego w Kolonii pod koniec 965 r. Propozycja taka wydaje się jednak mało prawdopodobna ze względu na znaczne oddalenie nadreńskiej metropolii. Zwrócić natomiast należy przede wszystkim uwagę na dwa wielkie zjazdy odbyte przez cesarza na wschodnich rubieżach Saksonii: w Magdeburgu na przełomie czerwca i lipca 965 oraz w Kwedlinburgu wiosną 966 r. Ważny jest zwłaszcza ten pierwszy. Zwołano go bezpośrednio po zaszłym 20 V 965 r. zgonie margrabiego Gerona, który zarządzał dotąd całym wschodnim pograniczem cesarstwa. Po jego śmierci Otto zdecydował

${ }^{56}$ V. E p p, Amicitia. Zur Geschichte personaler, sozialer, politischer und geistlicher Beziehungen im frühen Mittelalter, Stuttgart 1999.

57 Tamże, s. 218-229.

${ }_{58}$ A. P le s z c zy ń s ki, Niemcy, s. 63-64.

${ }^{59}$ E. Mü 11 e r - M e r t e n s, Die Reichsstruktur im Spiegel der Herrschaftspraxis Ottos des Grossen, Berlin 1980, s. 280-282; podstawowym źródłem do rekonstrukcji podróży władcy są dokumenty zebrane w MGH Diplomata regum et imperatorum Germaniae, t. I, Hannover 1879-1884 (dalej cyt.: DD OI).

${ }^{60}$ Annales Hildesheimenses, wyd. G. Waitz, Scriptores rerum Germanicarum, Hannover 1878, s. 22: annum integrum ad regnum Saxonum manebat interimque omnes suos adunavit ad pacem et concordiam. 
się zreformować system zarządu tych ziem, dzieląc je na pięć nowych, znacznie mniejszych i słabszych marchii ${ }^{61}$. Kryły się za tym różne motywacje - jak obawa przed dalszym skupianiem zbyt wielkiej władzy w jednym ręku czy pragnienie awansowania szerszego grona osób - ale zmiany te oznaczały w każdym razie całkowitą przebudowę systemu politycznego na wschodzie. Nie do pomyślenia wydaje się, by w system ten nie zamierzano wmontować także Mieszka, który jawił się jako cenny partner do utrzymywania w ryzach niebezpiecznych wciąż Wieletów ${ }^{62}$. O nadziejach wiązanych z piastowskim księciem świadczą pochlebne (i chyba przesadne) opinie o jego potędze, zawarte w pochodzącej właśnie z ok. 965 r. relacji Ibrahima ibn Jakuba, który informacje te uzyskał najpewniej na dworze cesarskim, może z ust samego Ottona ${ }^{63}$. W tych warunkach oczywista wydaje się osobista obecność Mieszka na tym spotkaniu. To tu najpewniej zawiązała się jego „przyjaźń” z cesarzem, niezależnie od wcześniej ustanowionego obowiązku trybutarnego. Dodajmy jeszcze, że rozważano wtedy na pewno także sprawy organizacji kościelnej Słowiańszczyzny. Niemal wszystkie wystawiane wtedy w Magdeburgu dokumenty cesarskie dotyczyły bowiem przygotowań do fundacji miejscowego arcybiskupstwa ${ }^{64}$.

Kłopot $\mathrm{w}$ tym, że Mieszko, nowy amicus imperatoris na wschodzie, był poganinem. Awansowanie go do roli „przyjaciela” wymagało ochrzczenia go. Większość historyków wyobrażała sobie chrzest Mieszka podobnie jak nasi najdawniejsi kronikarze - książę pod wpływem pobożnej żony postanowił się ochrzcić i po prostu to uczynił. Rzecz w istocie nie mogła wyglądać tak prosto. Wziąć trzeba pod uwagę choćby okoliczność, że akt tej rangi wymagał zasadniczo udziału biskupa ${ }^{65}$ - a najbliżsi biskupi byli w saskim Havelbergu i Brandenburgu oraz bawarskiej Ratyzbonie. W zasadzie tylko H. Łowmiański (a wcześniej W. Abraham) dostrzegał konieczność uprzedniego dokonania uzgodnień z cesarzem, J. Dowiat zaś przypuszczał, że książę udał się do Ratyzbony - ale oba pomysły nie przyjęły się w historiografii. Odwołać się natomiast warto do badań ks. Arnolda Angenendta nad problemem duchowego patronatu w przypadku chrztów władców ${ }^{66}$. Pokazał on „,modelowe” działania

${ }^{61}$ R. Kö p ke, E. D ü m m s e r, Kaiser Otto der Große (Jahrbücher der deutschen Geschichte), Leipzig 1876, s. 386-389; J. L a u d a g e, Otto der Grosse (912-973). Eine Biographie, Regensburg 2012, s. 211-212; A. Sti eld orf, Marken und Markgrafen. Studien zur Grenzsicherung durch die fränkisch-deutschen Herrscher, Hannover 2012 (Schriften der MGH 64), s. 242.

${ }^{62}$ Tytuł marchio, przydany Mieszkowi we wpisie nekrologicznym z Fuldy (MGH Scriptores, t. XIII, Hannover 1881, s. 206), świadczy o postrzeganiu go w Niemczech jako jednego z gwarantów porządku na pograniczu (A. S ti e ld or f, Marken, s. 258).

${ }^{63}$ Relacja Ibrahima ibn Ja'kūba z podróży do krajów słowiańskich, wyd. T. Kowalski, MPH series nova, t. I, Kraków 1946, s. 50; zob. G. L a b u d a, Ibrahim ibn Jakub. Najstarsza relacja o Polsce w nowym wydaniu, Roczniki Historyczne 16, 1947, s. 100-181; D. Tř e š tík, „Eine große Stadt der Slawen namens Prag” (Staaten und Sklaven in Mitteleuropa im 10. Jahrhundert), w: Boleslav II. Der tschechische Staat um das Jahr 1000, Praha 2001 (Colloquia mediaevalia Pragensia 2), s. 135-138; D. A. S i k o r s k i, Początki Kościoła, s. 20-44.

${ }^{64}$ MGH DD OI nr 296, 298-301; innych spraw dotyczą tylko dokumenty nr 295 (biskupstwa duńskie) i 297 (biskupstwo Verden). Zob. też J. L a u d a g e, Otto der Grosse, s. 212.

${ }^{65}$ Zob. niżej, przyp. 74.

${ }^{66}$ A. A n g e n e n d t, Kaiserherrschaft und Königstaufe. Kaiser, Könige und Päpste als geistliche Patrone in der abendländischen Missionsgeschichte, Berlin - New York 1984. 
cesarzy chrześcijańskich, którzy przyjmując pod swe zwierzchnictwo pogańskich władców, dokonywali jednocześnie ich chrztu i zostawali przy tej okazji ich ojcami chrzestnymi. Oznaczało to zawiązanie między nimi dodatkowej więzi duchowej i stanowiło zarazem formę wprowadzenia nowych członków do „rodziny królów” chrześcijańskich. Praktykę taką stosowali powszechnie cesarze bizantyjscy, a za ich przykładem także Karolingowie. Dla ich epoki szczególnie wyrazisty przykład przynosi opisany dokładnie w źródłach chrzest duńskiego króla Haralda, który zjawił się w 826 r. z rodziną i znacznym orszakiem w Moguncji u cesarza Ludwika Pobożnego i przyjął tam chrzest, przy czym to sam cesarz ,podniósł go z wody i własnoręcznie założył nań białą szatę", stając się tym samym ojcem chrzestnym. Ochrzczono następnie żonę i syna Haralda, których rodzicami chrzestnymi zostali odpowiednio cesarzowa Judyta i cesarski syn Lotar. Ochrzczeni Duńczycy udali się potem do pałacu, gdzie zostali hojnie obdarzeni, a Haraldowi sam cesarz założył purpurową szatę i koronę, co podkreślało polityczną wymowę aktu - uznanie za króla ${ }^{67}$. Z bliższych nam przykładów wspomnijmy przybycie do króla Ludwika (Niemieckiego) do Ratyzbony w 845 r. książąt czeskich, którzy poprosili o chrzest i otrzymali go ${ }^{68}$. Z czasów ottońskich A. Angenendt nie zna już wprawdzie wielu przykładów funkcjonowania tego modelu nawiązywania stosunków z poganami, ale milczenie źródeł - zawsze wszak przypadkowo tylko zachowanych - nie przesądza o faktycznym jego zarzuceniu. Wśród nielicznych świadectw źródłowych jest przekazana przez Adama z Bremy (piszącego sto lat później, ok. 1070-1085) historia innego króla duńskiego, Haralda Sinozębego, który po chrzest przybył do cesarza Ottona $^{69}$. Nie jest ona wprawdzie całkiem pewna - niektóre szczegóły opowieści są nieprawdziwe, a współczesny wypadkom Widukind w historii nawrócenia Haralda eksponuje inny zgoła aspekt cudu, którym misjonarz Poppa przekonać miał sceptycznego wobec nowej wiary władcę ${ }^{70}$ - ale nawet gdyby miała okazać się zmyślona, to pokazuje w każdym razie, że taka właśnie sytuacja (przybycie po chrzest do cesarza, który zostaje ojcem chrzestnym) uważana była wciąż za wzorcową. W literaturze przyjmuje się, że chrzest Haralda Sinozębego, który - jak wynika z kontekstu politycznego - przypadać musiał na pewno około połowy lat sześćdziesiątych X w., dokonał się właśnie podczas wspomnianego zjazdu w Magdeburgu w 965 r. $^{71}$ Istotną wskazówkę stanowi tu fakt, że Otto wystawił wówczas (26 VI 965) dokument dotyczący uposażenia biskupstw w Danii ${ }^{72}$. Termin nie był co prawda właściwy dla przeprowadzenia obrzędu chrzcielnego. Normy liturgiczne nakazywały udzielać chrztów zasadniczo w Wielką Sobotę lub ewentualnie w wigilię Zesłania Ducha Św. (w 965 r. dni te wypadały 25 marca i 13 maja, kiedy cesarz był odpowiednio w Ingelheim i Erstein) $)^{73}$,

67 Tamże, s. 215 n.

${ }_{68}$ Zob. niżej, przyp. 87.

${ }^{69}$ Adam von Bremen, Hamburgische Kirchengeschichte, II 3, wyd. B. Schmeidler, Scriptores rerum Germanicarum, wyd. 3, Hannover-Leipzig 1917, s. 63-64.

70 Widukind III 65, s. 140-141.

${ }^{71}$ R. Kö p k e, E. D ü m m s e r, Kaiser Otto der Große, s. 392; H. K e 11 e r, G. A 1 t h o ff, Die Zeit, s. 235-236.

${ }^{72}$ MGH DD OI, nr 295.

73 Tamże, nr 278 (Ingelheim 28 III), 284 (Erstein 12 V). 
ale dopuszczane były też uzasadnione różnymi potrzebami odstępstwa od tej reguły ${ }^{74}$. W przypadku chrztów władców decydować mogły przede wszystkim racje polityczne i samo pojawienie się danego kandydata na dworze cesarskim. Wydaje się prawdopodobne, że na tym samym zjeździe w Magdeburgu ochrzczono także naszego Mieszka, który był tam wszak, przypomnijmy, niewątpliwie obecny. Zauważmy, że amicitia mogła wyrażać także stosunek pokrewieństwa duchowego wynikający $\mathrm{z}$ trzymania do $\mathrm{chrztu}^{75}$. W literaturze od dawna traktuje się łącznie oba dokonane w podobnym czasie chrzty pogańskich sąsiadów cesarstwa ${ }^{76}$. Może odbyły się one rzeczywiście jednocześnie. Obecność cesarza w Magdeburgu poświadczona jest między 26 czerwca a 9 lipca. Cesarz przybył krótko przedtem (17 czerwca był w Derenburgu opodal Halberstadt) i wyjechał krótko potem (15 lipca był już w Kwedlinburgu ${ }^{77}$. Domniemany chrzest Haralda i Mieszka kłaść należy najpewniej na sam początek kilkutygodniowego zjazdu. Wspomniany przed chwilą dyplom cesarski dla biskupstw duńskich jest pierwszym świadectwem pobytu wystawcy w Magdeburgu. Ponieważ obaj kandydaci do chrztu, zwłaszcza zaś Mieszko, odgrywali sporą rolę w planach politycznych Ottona, należało jak najszybciej zadbać o uczynienie z nich chrześcijan.

Trzymając się założenia - które wydaje się wysoce prawdopodobne - że Mieszko przyjął chrzest na dworze cesarskim z udziałem Ottona Wielkiego, można jednak wskazać też konkurencyjne miejsce i czas. Dobrym terminem wydaje się również zjazd w Kwedlinburgu wiosną $966 \mathrm{r}^{78}$ Okazja była niezwykle uroczysta, a zjazd miał głęboką wymowę religijną i polityczną. Otto obchodził obłóczyny swej wstępującej do klasztoru córki Matyldy. Było to też pożegnanie, postanowiony już był bowiem ponowny wyjazd władcy do Italii, gdzie trzeba było tłumić niepokoje rzymskie. Ze względu na charakter uroczystości obecni byli członkowie najbliższej rodziny cesarskiej, a także liczni książęta i cały podobno episkopat. Zgromadzić się mieli „wszyscy dostojnicy kraju”79. Choć nie jest to poświadczone żadnymi źródłami, wydaje się oczywiste, że w tak wielkim zgromadzeniu powinien uczestniczyć także Mieszko - tym bardziej że jedną z niezałatwionych przed odjazdem trosk cesarza była napięta sytuacja na froncie wieleckim i sprawa Wichmana, w których piastowski

${ }^{74}$ A. A n g e n e nd t, Kaiserherrschaft, s. 31-32 (o terminach), 45 (o prawach biskupa); w polskiej literaturze J. D o w i a t, Metryka, s. 28-32.

${ }^{75}$ V. E p p, Amicitia, s. 150.

${ }^{76}$ Tak już W. G i e s e b r e c h t, Geschichte der deutschen Kaiserzeit, t. I, wyd. 2, Braunschweig 1860, s. 489, który oba chrzty zrelacjonował pod 966 r. Zob. wyżej, przyp. 71.

77 MGH DD OI, nr 293 (Derenburg), 294-301 (Magdeburg), 302 (Kwedlinburg).

${ }_{78}$ R. Kö p k e, E. D ü m m s e r, Kaiser Otto der Große, s. 406.

79 Die Reichschronik des Annalista Saxo, wyd. K. Nass, MGH Scriptores, t. XXXVII, Hannover 2006, s. 205: Eodem anno antequam rex iret in Italiam, Machtild unica filia eius, decum sanctimonialium communi consensu cleri et populi religiosissime congregationis sancti Seruatii in abbatissam electa est ac presentibus patre Ottone inperatore et matre Athelheide inperatrice aviaque sua Machtilde regina necnon rege Ottone fratre suo cunctisque optimatibus regionis illius utriusque sexus non uno, uti moris est, benedicente episcopo, sed cunctis regni archiepiscopis et episcopis in hoc opus collectis benedicta est. Przekaz oparty jest najpewniej na zaginionych Annales Quedlinburgenses, zob. MGH Scriptores rerum Germanicarum, t. 72, wyd. M. Giese, Hannover 2004, s. 319. 
władca odgrywał kluczową rolę ${ }^{80}$. Obecność cesarza w Kwedlinburgu mamy wprawdzie poświadczoną tylko 22 i 23 kwietnia, ale udokumentowane itinerarium zawiera przedtem i potem znaczne luki - poprzedni pobyt znamy 1 marca w Duisburgu, następny dopiero 17 lipca w Siptenfelde w północnej Turyngii, odległym o kilkanaście kilometrów od Kwedlinburga ${ }^{81}$. Zjazd kwedlinburski trwać mógł zatem długo. Ponieważ 22 kwietnia wypadała Niedziela Przewodnia, nie może ulegać wątpliwości, że Otto spędził w Kwedlinburgu całe święta wielkanocne, co najmniej od Niedzieli Palmowej (8 kwietnia). Mieściła się więc w tym okresie Wielka Sobota, najwłaściwszy termin chrztu. Świętowanie Wielkiejnocy właśnie w Kwedlinburgu zdarzało się zresztą Ottonowi częściej i można uznać to za zwyczajową praktykę ${ }^{82}$. Możliwe zresztą, że cesarz pozostał też na miejscu przez obchody Zesłania Ducha Św. (3 czerwca) $)^{83}$.

Mamy zatem do wyboru dwa sugerowane terminy chrztu Mieszka: przełom czerwca i lipca 965 w Magdeburgu albo sobota wielkanocna 14 IV 966 r. w Kwedlinburgu ${ }^{84}$. Ten drugi zgodny jest wymogami liturgicznymi, a także $z$ datą roczną przekazaną przez polską annalistykę, ale ta ostatnia okoliczność - w świetle wskazanych wyżej wątpliwości co do wiarogodności roczników - nie ma większego znaczenia. Można by zresztą próbować pogodzić obie możliwości założeniem, że w Magdeburgu w 965 dokonano tylko wstępnych ustaleń w sprawie chrztu piastowskiego księcia, który dopełniono następnie w Kwedlinburgu na Wielkanoc 966 r. ${ }^{85}$ Od katechumena Kościół wymagał pierwotnie trzyletniego okresu przygotowania przed przyjęciem sakramentu, ale wcześnie też, pod wpływem praktyki chrzczenia dzieci, zaczęto odstępować od tego zwyczaju ${ }^{86}$. Zwłaszcza władcy nie musieli podlegać takim wymogom. Zauważmy, że opisywane w źródłach chrzty pogańskich

${ }^{80} \mathrm{O}$ głębokiej trosce Ottona o sprawy wieleckie świadczy jego list do książąt saskich pisany z Kapui 18 I 968 r., pod wrażeniem wiadomości o śmierci Wichmana (Widukind III 70, s. $146-147=$ MGH DD OI, nr 355).

${ }^{81}$ MGH DD OI, nr 325 (Duisburg), 326-327 (Kwedlinburg), 328 (Siptenfelde).

${ }^{82}$ W Kwedlinburgu Otto spędzał Wielkanoc w 1. 940, 941, 948, 959, 966 i 973 i było to ulubione przezeń miejsca celebrowania tych świąt (E. Müller-Mertens, Die Reichsstruktur, s. 267-269, tabl. 2-3).

${ }^{83}$ Po opuszczeniu Kwedlinburga cesarz zabawił jeszcze tydzień w Nordhausen i to tam pożegnał się ostatecznie z matką, ale pobyt ten nie daje się dokładnie wydatować (Die Lebensbeschreibungen der Königin Mathilde, wyd. B. Schütte, Scriptores rerum Germanicarum, Hannover 1996, s. 134 [Vita antiquior], 189-193 [Vita posterior]; R. K ö p k e, E. D ü m m s e r, Kaiser Otto der Große, s. 406-407).

${ }^{84}$ O krok od takiego samego rozwiązania był A. P 1 e s z c z y ń s k i, Niemcy, s. 64, który z jednym z tym zjazdów pragnął łączyć nawiązanie „,przyjaźni” Mieszka z Ottonem, ale w ostatniej chwili się zawahał: „Niekoniecznie jednak trzeba datę interesującego nas układu wiązać z przyjęciem chrztu przez władcę piastowskiego". Wcześniej już S. Traw k ow s k i, Jak powstawała Polska, wyd. 4, Warszawa 1966, s. 168-169, sugerował, że być może Mieszko przyjął chrzest w Kolonii na Boże Narodzenie 965 r., według rachuby a Nativitate - już w 966 r.; potem jednak badacz ten wycofał się z tego pomysłu (zob. t e n ż e, Początki Kościoła w Polsce za panowania Mieszka I, w: Polska Mieszka I, Poznań 1993, s. 59-62).

${ }^{85}$ Podobne etapy zakładał H. Ło w m i a ń s k i, Imię, s. 343-344; t e n ż e, Początki, t. V, S. $588-590$.

${ }^{86}$ A. A n ge nend t, Kaiserherrschaft, s. 25. 
książąt są przedstawieniami w jednym akcie - człowiek taki przybywa do cesarza, prosi o chrzest i od razu go otrzymuje. Tak było w przypadku obu duńskich Haraldów, tak było z czternastu książętami czeskimi, którzy w 845 r. przybyli do króla Ludwika do Ratyzbony, poprosili o chrzest i otrzymali go „w oktawie Objawienia Pańskiego" (13 stycznia) ${ }^{87}$. Święty Metody miał nawet rozwiewać wątpliwości czeskiego Borzywoja, że na chrzest nie trzeba wcale czekać ${ }^{88}$. Także Mieszka ochrzczono najpewniej za pierwszym jego pojawieniem się na dworze cesarskim. Za bardziej prawdopodobną datę uznać więc jednak trzeba rok 965.

Przyjęcie tej sugestii oznacza, że daty podane przez polskie rocznikarstwo są najpewniej przesunięte. Tylko zresztą o rok, co nie stanowi bynajmniej nadzwyczajnej sytuacji. Rewizja daty chrztu pociąga też za sobą konieczność poprawienia innych dat, zwłaszcza daty ślubu Mieszka (rok urodzin Bolesława Chrobrego i tak wydawał się wielu badaczom podejrzany). Jeśli książę ochrzcił się w 965 r., to „Dobrawa przybyła” do niego co najmniej rok wcześniej, zważywszy wspomniane przez Thietmara łamanie przez nią Wielkiego Postu ${ }^{89}$ (a założyć chyba możemy, że w ostatnich tygodniach przed przyjęciem chrztu przez męża książęca para przestała już grzeszyć w czasie zakazanym). Gdyby Dobrawa robiła to, jak opowiadali jedni, w jednym roku, oznaczałoby to ślub w 963 lub początkach 964 r.; gdyby zaś w trzech kolejnych latach, to przesunąc by go trzeba aż na 961 lub początek $962 \mathrm{r}$.

$\mathrm{W}$ proponowanej rekonstrukcji idę $\mathrm{w}$ gruncie rzeczy tropem wyznaczonym przez H. Łowmiańskiego ${ }^{90}$. Jemu zawdzięczam podstawową myśl, że chrzest Mieszka łączyć należy z nawiązaniem stosunków z cesarzem, czemu tak usilnie starali się zaprzeczać inni polscy badacze. Kreślony przez Łowmiańskiego obraz wymaga jednak, jak sądzę, korekty w kwestii daty, a przede wszystkim miejsca odbycia tego obrzędu. Niezależnie od przyjęcia jednego z dwóch zaproponowanych przed chwilą rozwiązań, uważam, że książę przyjął chrzest podczas wizyty na dworze cesarskim w Niemczech. Jest to sprzeczne z dość powszechnie przyjmowanym w naszej literaturze wyobrażeniem. Tylko J. Dowiat dowodził, przypomnijmy ${ }^{11}$, że Mieszko chrzczony był w bawarskiej Ratyzbonie. Hipoteza jest chybiona o tyle, że ta domniemana uroczystość koliduje ze zjazdem wielkanocnym w Kwedlinburgu, w którym uczestniczyć mieli „wszyscy biskupi" niemieccy - a więc przypuszczalnie też Michał ratyzboński. Zdecydowanie przeważa jednak pogląd, że chrzest Mieszka musiał odbyć się w kraju, a punkt ciężkości dyskusji przesuwa się na spory o konkretne miejsce, przy czym

87 Annales Fuldenses sive Annales Regni Francorum Orientalis, wyd. F. Kurze, Scriptores rerum Germanicarum, Hannover 1891, s. 35.

${ }^{88}$ Według tzw. Legendy Krystiana czeski książę Borzywoj zapytał namawiającego go do chrztu św. Metodego: Et si, inquit Borivoi, res se ita habet, que mora est baptizandi? Nulla, inquit pontifex, tantum paratus esto ex integro corde credere in Deum. I już nazajutrz: Mane facto ipsum ducem cum suis triginta, qui advenerant, cathezizans, peractis ieiuniorum ex more sollempniis, sacrosancto baptismati fonte innovavit (Legenda Christiani. Vita et passio sancti Wenceslai et sancte Ludmile ave eius, cap. 2, wyd. J. Ludvíkovský, Praha 1978, s. 20).

${ }^{89}$ Zob. wyżej, przyp. 17. Ch. L ü b k e, Regesten, t. II, s. 173-174, datował ślub Mieszka z Dobrawą na 963/964 r.

90 Zob. wyżej, przyp. 48.

91 Zob. wyżej, przyp. 50. 
preferuje się Poznań i Ostrów Lednicki ${ }^{92}$. Przekonanie o chrzcie krajowym wspiera się na dwóch zasadniczych przesłankach ${ }^{93}$. Pierwszą stanowi ocena losów opisanego w Żywocie św. Metodego (z końca IX w.) „potężnego księcia siedzącego w Wiśle”, któremu święty przepowiedział, że skoro nie chce się ochrzcić „dobrowolnie na swojej ziemi”, zostanie „pojmany i zmuszony przyjąć chrzest na cudzej ziemi”"94. Chrzest na „cudzej ziemi” jawi się tu jako hańbiący dopust, którego Mieszko chciałby na pewno uniknąć. Czy jednak ten pojedynczy przekaz można uogólniać? Można mu przeciwstawić szereg innych przykładów władców przyjmujących dobrowolnie chrzest w obcym kraju. Według czeskiej Legendy Krystiana (pochodzącej być może jeszcze z X w.) książę Borzywoj ochrzcił się podczas wizyty na Morawach, namówiony do tego przez św. Metodego. Tu w chrzcie na obcej ziemi nie ma nic uwłaczającego ${ }^{95}$. Przypomnijmy też wspomnianych już wyżej czternastu książąt czeskich proszących o chrzest w 845 r., obu duńskich Haraldów i całą praktykę przyjmowania chrztu na dworze cesarskim ${ }^{96}$. Przykład księcia „w Wiśle” nie jest więc na tym tle miarodajny, a zresztą istota tej relacji tkwi nie w samej lokalizacji miejsca chrztu, która ma znaczenie pochodne wobec podstawowego rozróżnienia między chrztem dobrowolnym i przyjmowanym pod przymusem ${ }^{97}$. Najważniejsza jednak dla zwolenników chrztu w kraju jest argumentacja ex silentio - żadne wszak źródło niemieckie nie zauważyło przybycia piastowskiego księcia pragnącego przyjąć chrzest. Podstawowe przekazy, kroniki Widukinda i Thietmara, lata te opisują jednak dość skąpo. Zadać sobie zresztą trzeba pytanie, czy był to rzeczywiście fakt wymagający dostrzeżenia. Zauważmy, że żadne źródło współczesne nie odnotowało również chrztu Haralda Sinozębego. Widukind wiedział o jego nawróceniu, ale za stosowne uznał opisać inne związane z nim wydarzenie. Sam chrzest zrelacjonował dopiero późniejszy Adam z Bremy, zainteresowany jednak tym faktem w kontekście dziejów duńskich ${ }^{98}$. Z punktu widzenia obserwatorów niemieckich wydarzenie takie nie musiało wcale budzić zainteresowania. Sprawę można by nawet odwrócić. Ciekawsza wydawać się mogła raczej podróż któregoś z biskupów do dalekiego kraju w celu udzielenia tam chrztu miejscowemu księciu' ${ }^{99}$.

92 Dyskusję streszcza J. D o b o s z, Monarchia, s. 47-48, a zob. też D. A. S i k o r s ki, Kościól, s. 107-129.

93 T. J a s iń s ki, Geneza i okoliczności chrztu Mieszka I w 966 r. (w druku); autorowi serdecznie dziękuję za udostępnienie mi tego tekstu przed publikacją.

94 Żywoty Konstantyna i Metodego (obszerne), wyd. T. Lehr-Spławiński, Poznań 1959, s. 115; o źródle tym J. L e ś n y, Żywoty Konstantyna i Metodego, w: Słownik starożytności słowiańskich, t. VII, Wrocław 1982, s. 309-312.

95 Legenda Christiani, cap. 2, s. 18-20.

96 Zob. wyżej, przyp. 66-72. Adam z Bremy objaśnia chrzest Haralda Sinozębego klęską zadaną mu przez cesarza, ale wiemy dziś, że to nieprawda (A. A n g e n e n d t, Kaiserherrschaft, s. 277). Niejasna jest sprawa z miejscem chrztu św. Włodzimierza, na temat czego funkcjonowały różne wersje; ta najbardziej prawdopodobna wskazywała Chersones krymski (Korsuń), ale książę znaleźć się tam miał jako zdobywca (Повесть временных лет, выд. Д. С. Лихачев, Санкт Петербург 1996, s. 49-51).

${ }_{97}$ J. D o w i a t, Metryka, s. 55-56.

${ }^{98}$ Zob. wyżej, przyp. 69.

99 Różni autorzy dostrzegli np. fakt, że przyszły arcybiskup magdeburski Adalbert pojechał jako biskup misyjny na Ruś (Thietmar II 22, s. 64; thum. pol., s. 72; Reginonis Chronicon, s. 170, 172), choć jego dwuletni pobyt trudno oczywiście porównać z krótką podróżą do kraju Polan. 
Dziejopisowie mają zawsze własne priorytety, nie zawsze dla nas oczywiste. Tak było w średniowieczu i tak jest współcześnie. Dość zauważyć, że także najnowszy biografista Ottona Wielkiego, Johannes Laudage, choć poświęcił cały rozdział polityce słowiańskiej swego bohatera ${ }^{100}$, nie zauważył w ogóle istnienia naszego Mieszka.

\section{BIBLIOGRAFIA}

Abraham W., Organizacja Kościoła w Polsce do połowy XII wieku, wyd. 3, Poznań 1962.

Adam von Bremen, Hamburgische Kirchengeschichte, II 3, wyd. B. Schmeidler, Scriptores rerum Germanicarum, wyd. 3, Hannover-Leipzig 1917.

Althoff G., Otto der Große und die neue europäische Identität, w: Der Hoftag in Quedlinburg 973. Von den historischen Wurzeln zum Neuen Europa, Berlin 2006.

Althoff G., Wichmann, w: Lexikon des Mittelalters, t. IX, 1999.

Angenendt A., Kaiserherrschaft und Königstaufe. Kaiser, Könige und Päpste als geistliche Patrone in der abendländischen Missionsgeschichte, Berlin - New York 1984.

Annales Fuldenses sive Annales Regni Francorum Orientalis, wyd. F. Kurze, Scriptores rerum Germanicarum, Hannover 1891.

Annales Hildesheimenses, wyd. G. Waitz, Scriptores rerum Germanicarum, Hannover 1878.

Annales Quedlinburgenses, Monumenta Germaniae historica, Scriptores rerum Germanicarum, t. 72, wyd. M. Giese, Hannover 2004, s. 319.

Balzer O., Genealogia Piastów, wyd. 2, Kraków 2005.

Barański M. K., Dynastia Piastów w Polsce, Warszawa 2005.

Bogdanowicz P., Chrzest Polski, Nasza Przeszłość 23, 1966.

Budkowa Z., Początki polskiego rocznikarstwa, Studia Źródłoznawcze 2, 1958.

Die Chronik des Bischofs Thietmar von Merseburg, wyd. R. Holtzmann, Monumenta Germaniae historica, Scriptores rerum Germanicarum, nova series, t. IX, Berlin 1935.

Die Lebensbeschreibungen der Königin Mathilde, wyd. B. Schütte, Scriptores rerum Germanicarum, Hannover 1996.

Die Reichschronik des Annalista Saxo, wyd. K. Nass, Monumenta Germaniae historica, Scriptores, t. XXXVII, Hannover 2006.

Die Sachsengeschichte des Widukind von Korvei, wyd. H.-E. Lohmann, P. Hirsch, Scriptores rerum Germanicarum, Hannover 1935.

Dobosz J., Monarchia i możni wobec Kościoła w Polsce do początku XIII wieku, Poznań 2002.

Dowiat J., Chrzest Polski, Warszawa 1966.

Dowiat J., Metryka chrztu Mieszka I i jej geneza, Warszawa 1961.

Drelicharz W., Idea zjednoczenia królestwa w średniowiecznym dziejopisarstwie polskim, Kraków 2012.

Epp V., Amicitia. Zur Geschichte personaler, sozialer, politischer und geistlicher Beziehungen im frühen Mittelalter, Stuttgart 1999.

Fried J., Der Weg in die Geschichte. Die Ursprünge Deutschlands bis 1024, Berlin 1998.

Giesebrecht W., Geschichte der deutschen Kaiserzeit, t. I, wyd. 2, Braunschweig 1860.

Holtzmann R., Geschichte der sächsischen Kaiserzeit (900-1024), München 1941.

Jasiński K., Najdawniejsze roczniki krakowskie, Kwartalnik Historyczny 88, 1981.

Jasiński K., Rodowód pierwszych Piastów, wyd. 2, Poznań 2004.

Jasiński T., Czy państwo polskie za Mieszka I było suwerenne?, w: Studia nad dawną Polską, t. II, Gniezno 2009.

Jasiński T., Geneza i okoliczności chrztu Mieszka I w 966 r. (w druku).

Jasiński T., Początki organizacji kościelnej w Polsce, w: Tu się wszystko zaczęło. Rola Poznania w państwie pierwszych Piastów, Poznań 2010.

100 J. L a u d a g e, Otto der Grosse, s. 224-230. 
Jasiński T., Początki polskiej annalistyki, w: Nihil superfluum esse. Studia z dziejów średniowiecza ofiarowane profesor Jadwidze Krzyżaniakowej, Poznań 2000.

Jasiński T., Rocznik obcy w „Roczniku kapituły krakowskiej”, w: Scriptura custos memoriae. Prace historyczne, Poznań 2001.

Jasiński T., Rocznik poznański. Ze studiów nad annalistyką polską i czeską, w: Aetas media, aetas moderna. Studia ofiarowane profesorowi Henrykowi Samsonowiczowi w siedemdziesiątą rocznicę urodzin, Warszawa 2000.

Jasiński T., Rola Rocznika augijskiego w rozwoju annalistyki polskiej i niemieckiej, Roczniki Historyczne 69, 2003.

Jasiński T., Zagadnienie autorstwa Rocznika obcego. Przyczynek do dziejów historiografii niemieckiej X stulecia, Roczniki Historyczne 68, 2002.

Jedlicki M. Z., Stosunek prawny Polski do Cesarstwa do r. 1000, Poznań 1939.

Jurek T., Usque in Vurta fluvium. Nad trybutem Mieszkowym, Kwartalnik Historyczny (w druku).

Kehr P., Das Erzbistum Magdeburg und die erste Organisation der christlichen Kirche in Polen, Abhandlungen der Preussischen Akademie der Wissenschaften, Philosophisch-Historische Klasse 1920, nr 1 (przedruk w: tegoż, Ausgewählte Schriften, Göttingen 2005, t. II).

Keller H., Althoff G., Die Zeit der späteren Karolinger und der Ottonen. Krisen und Konsolidierungen 888-1024 (Gebhardt. Handbuch der deutschen Geschichte, wyd. 10, t. III), Stuttgart 2008.

Köpke R., Dümmser E., Kaiser Otto der Große (Jahrbücher der deutschen Geschichte), Leipzig 1876.

Kronika Thietmara, wyd. M. Z. Jedlicki, Poznań 1953.

Labuda G. Pierwsze wieki monarchii piastowskiej, Poznań 2012.

Labuda G., Główne linie rozwoju rocznikarstwa polskiego w wiekach średnich, Kwartalnik historyczny 78, 1971.

Labuda G., Ibrahim ibn Jakub. Najstarsza relacja o Polsce w nowym wydaniu, Roczniki Historyczne 16, 1947.

Labuda G., Jakimi drogami przyszło do Polski chrześcijaństwo?, Nasza Przeszłość 69, 1988.

Labuda G., Jeden czy dwa roczniki niemieckie u podstaw polskiego rocznikarstwa?, Studia Źródłoznawcze 39, 2001.

Labuda G., Magdeburg i Poznań (Założenie arcybiskupstwa magdeburskiego i biskupstwa poznańskiego na tle wschodniej polityki misyjnej Ottona Wielkiego), Roczniki Historyczne $14,1938$.

Labuda G., Mieszko I, Wrocław 2002.

Labuda G., Studia nad początkami państwa polskiego, Poznań 1946.

Labuda G., Studia nad początkami państwa polskiego, wyd. 2, t. I, Poznań 1987.

Laudage J., Otto der Grosse (912-973). Eine Biographie, Regensburg 2012.

Legenda Christiani. Vita et passio sancti Wenceslai et sancte Ludmile ave eius, wyd. J. Ludvíkovský, Praha 1978.

Leśny J., Żywoty Konstantyna i Metodego, w: Słownik starożytności słowiańskich, t. VII, Wrocław 1982.

Ludat H., Die Anfänge des polnischen Staates, Krakau 1942.

Łowmiański H., Imię chrzestne Mieszka I, Slavia Occidentalis 19, 1958 (przedruk w: tegoż, Studia nad dziejami Słowiańszczyzny, Polski i Rusi w wiekach średnich, Poznań 1986).

Łowmiański H., Początki Polski, t. V, Warszawa 1973

Miśkiewicz B., w: Dzieje Polski, wyd. 4, Warszawa 1993.

Monumenta Germaniae historica, Diplomata regum et imperatorum Germaniae, t. I, Hannover 1879-1884.

Monumenta Germaniae historica, Libri memoriales et necrologia, nova series, t. II, Hannover 1983.

Monumenta Germaniae historica, Scriptores, t. XIII, Hannover 1881.

Müller-Mertens E., Die Reichsstruktur im Spiegel der Herrschaftspraxis Ottos des Grossen, Berlin 1980. 
Pleszczyński A., Die Taufe Polens - das Jahr 966, w: Religiöse Erinnerungsorte in Ostmitteleuropa. Konstitution und Konkurrenz im nationen- und epochenübergreifenden Zugriff, Berlin 2013.

Pleszczyński A., Niemcy wobec pierwszej monarchii piastowskiej (963-1034). Narodziny stereotypu. Postrzeganie i cywilizacyjna klasyfikacja władców Polski i ich kraju, Lublin 2008.

Повесть временных лет, выд. Д. С. Лихачев, Санкт Петербург 1996.

Reginonis abbatis Prumensis Chronicon cum continuatione Treverensi, wyd. F. Kurze, Scriptores rerum Germanicarum, Hannover 1890.

Relacja Ibrahima ibn Ja’ḳūba z podróży do krajów słowiańskich, wyd. T. Kowalski, Monumenta Poloniae historica, series nova, t. I, Kraków 1946.

Rocznik dawny, wyd. Z. Kozłowska-Budkowa, Monumenta Poloniae historica, series nova, t. V, Warszawa 1978.

Rocznik kamieniecki, Monumenta Poloniae historica, t. II, Lwów 1872.

Rocznik kapituły krakowskiej, wyd. Z. Kozłowska-Budkowa, Monumenta Poloniae historica, series nova, t. V, Warszawa 1978.

Rocznik kapituły poznańskiej, Monumenta Poloniae historica, series nova, t. VI, Warszawa 1962.

Rosik S., Początki Polski w kronikach niemieckich X-XI w. (w kręgu wiadomości Widukinda Gieysztor A., w: Historia Polski, t. I, cz.1, Warszawa 1957.

Samsonowicz H., Historia Polski do roku 1795, wyd. 2, Warszawa 1973.

Sikorski D. A., Kościół w Polsce za Mieszka I i Bolesława Chrobrego. Rozważania nad granicami poznania historycznego, Poznań 2011.

Sikorski D. A., O stosunkach polsko-niemieckich w X i XI wieku, Studia Historica Slavo-Germanica 26, 2004/2005 (wyd. 2006).

Sikorski D. A., Początki Kościoła w Polsce. Wybrane problemy, Poznań 2012.

Silnicki T., Początki organizacji kościoła w Polsce za Mieszka I i Bolesława Chrobrego, w: Początki Państwa Polskiego. Księga Tysiąclecia, t. I, Poznań 1962.

Sochacki J., Stosunki publicznoprawne między państwem polskim a Cesarstwem Rzymskim w latach 963-1102, Gdańsk 2003.

Stasiewski B., Die Anfänge der Christianisierung Polens auf dem Hintergrund der slavischen Missionsgeschichte des frühen Mittelalters, Münster 2014.

Stieldorf A., Marken und Markgrafen. Studien zur Grenzsicherung durch die fränkisch-deutschen Herrscher, Hannover 2012 (Schriften der MGH 64).

Strzelczyk J., Mieszko Pierwszy, Poznań 1992.

Sułowski Z., Chrzest Polski, Zeszyty Naukowe KUL, 1966, z. 1-2.

Szczur S., Historia Polski. Średniowiecze, Kraków 2002.

Trawkowski S., Jak powstawała Polska, wyd. 4, Warszawa 1966.

Trawkowski S., Początki Kościoła w Polsce za panowania Mieszka I, w: Polska Mieszka I, Poznań 1993.

Třeštík D., „Eine große Stadt der Slawen namens Prag” (Staaten und Sklaven in Mitteleuropa im 10. Jahrhundert), w: Boleslav II. Der tschechische Staat um das Jahr 1000, Praha 2001 (Colloquia mediaevalia Pragensia 2).

Tymieniecki K., Widukind i Thietmar o wypadkach z roku 963, Roczniki Historyczne 12, 1936.

Wedekind A. Ch., Noten zu einigen Geschichtsschreibern, cz. 3, Braunschweig 1833.

Wenta J., Roczniki Królestwa, w: Tekst źródła - krytyka - interpretacja, Warszawa 2005.

Węcowski P., Początki Polski w pamięci historycznej późnego średniowiecza, Kraków 2014.

Widajewicz J., Chrzest Polski, Życie i Myśl 1951, nr 2

Wyrozumski J., Dzieje Polski piastowskiej (VIII w. - 1370), Kraków 1999 (Wielka historia Polski, t. 2).

Zakrzewski S., Bolesław Chrobry Wielki, Lwów 1925.

Zakrzewski S., Mieszko I jako budowniczy państwa polskiego, Warszawa 1921 (wyd. 2, Kraków 2006) 
Zakrzewski S., Okres do schyłku XII w., w: Historia polityczna Polski, cz. 1, Warszawa 1920 (Encyklopedia polska, t. V, cz. 1 ).

Żywoty Konstantyna i Metodego (obszerne), wyd. T. Lehr-Spławiński, Poznań 1959.

\section{Zum Zeitpunkt und zu den Umständen der Taufe Mieszkos I.}

\section{Zusammenfassung}

Der Zeitpunkt der Taufe Mieszkos I. im Jahre 966 wird in der Geschichtsschreibung als schier unumstößlich angesehen. Die einzige Quellengrundlage zur Datierung dieses Aktes liefern polnische Annalen. Der entsprechende Eintrag in den erhaltenen Denkmälern stammt aus einem heute verlorenen, Ende des 10. Jahrhunderts an der Krakauer Domkirche angelegten Jahrbuch. Die Notiz ist wohl nicht gleichzeitig mit der Taufe niedergeschrieben worden (wie früher angenommen wurde), sondern mindestens zehn Jahre später. Die Jahresangabe ist also nicht absolut sicher. Da der Chronist Widukind von Corvey bei der Beschreibung der Ereignisse des Jahres 963 Mieszko als „Barbaren“ (also Heiden) behandelt, ihn aber 967 als „Freund des Kaisers" nennt (was ihn als Christen ausweist), müßte die Taufe zwischen diesen beiden Daten gespendet worden sein. Eine entscheidende Bedeutung haben die Umstände, unter denen die „Freundschaft" zwischen Mieszko und Kaiser Otto I. geschlossen wurde, was wohl während einer persönlichen Zusammenkunft stattfand und zweifelsohne mit der Annahme des Christentums durch den Herzog im Zusammenhang stand. Die Mehrheit der polnischen Historiker geht jedoch weiterhin davon aus, daß Mieszkos Taufe von Böhmen vermittelt wurde und ohne die Beteiligung des Kaisers erfolgte. Eine solche Lösung scheint völlig unwahrscheinlich zu sein. Denn eine häufige, beinahe modellhafte Praxis war im Früh- und Hochmittelalter die Taufe heidnischer Fürsten am kaiserlichen Hof. Otto der Große weilte von Anfang 965 bis Herbst 966 auf Reichsgebiet. Besondere Aufmerksamkeit muß man dabei dem Magdeburger Reichstag im Juni/Juli 965 und dem Quedlinburger Reichstag zu Ostern 966 schenken. Erstere Versammlung war der Neuordnung an den östlichen Reichsgrenzen nach dem Tode des Markgrafen Gero gewidmet, an der Mieszko nicht fehlen durfte. Damals wurde wohl der dänische König Harald Blauzahn getauft. Die Zusammenkunft in Quedlinburg fand wiederum zu Ostern statt (der Ostersamstag galt allgemein als ein geeigneter Tauftermin). Da ein Fürst (wie Analogien zeigen) bei der ersten Begegnung mit dem Kaiser getauft werden sollte, scheint der Tauftermin im Sommer 965 in Magdeburg am wahrscheinlichsten zu sein. Auf jeden Fall sollte anerkannt werden, daß Mieszko am Kaiserhof getauft wurde. Dieses Ereignis wurde freilich in deutschen Quellen nicht vermerkt, da einerseits nur wenige aus dieser Zeit erhalten blieben, sich andererseits ihre Autoren für die Taufe eines fremden Fürsten nicht unbedingt interessieren mußten.

Übersetzt von Waldemar Könighaus

\section{On the time and circumstances of Mieszko's baptism}

\section{Abstract}

The date of Mieszko I's baptism in 966 is regarded as absolutely certain. However, it is confirmed only by the annals in which it was recorded several decades later and thus may be imprecise. Mieszko was certainly baptised between 963 and 967, as can be inferred from the relation of the Saxon chronicler Widukind. Contrary to the dominant opinion of Polish historiography, the duke's baptism should be connected to the establishment of "friendship" with emperor Otto the Great. Analogies with other pagan rulers show that they often accepted baptism at the imperial court. Otto was in Germany from the beginning of 965 until the autumn of 
966, and special consideration should be paid to the large congresses in Magdeburg at the turn of June and July 965, and in Quedlinburg at the Easter of 966. Because the baptism assuredly took place at the first contact, the earlier of those dates seems more probable. In any case, it must be assumed that Mieszko was baptised in Germany.

Translated by Rafat T. Prinke 